\title{
Damping Properties of Natural rubber/ Epoxidized Natural Rubber composites with different fillers
}

\author{
Yueqiong Wang ${ }^{1, a}$, Lusheng Liao ${ }^{1, b^{*}}$, Hongtu Lin ${ }^{1, c}$, Fuquan Zhang ${ }^{1, d}$, Jieping \\ Zhong ${ }^{2, e}$, Kui $\mathrm{Xu}^{1 f}$, Zheng Peng ${ }^{1, g}$ \\ ${ }^{1}$ Agricultural Products Processing Research Institute, Chinese Academy of Tropical Agricultural \\ Sciences, Zhanjiang 524001 P. R. China \\ ${ }^{2}$ School of Science, Guangdong Ocean University, Zhanjiang 524088 P. R. China \\ ayqw215@163.com, *b276491692@qq.com, c 4344714@qq.com, ${ }^{\mathrm{d}} 355715841 @ q q . c o m$, \\ ezhongjieping0303@163.com, ${ }^{\mathrm{f}}$ kuixu9981@163.com, ${ }^{\mathrm{g}}$ zpengcatas@126.com
}

Keywords: damping properties, natural rubber, epoxidized natural rubber, composites Abstract. Natural rubber(NR)/Epoxidized Natural Rubber(ENR)/Carbon black(CB), $\mathrm{NR} / \mathrm{ENR} /$ silica $\left(\mathrm{SiO}_{2}\right), \mathrm{NR} / \mathrm{ENR} /$ montmorillonoid(MMT) and NR/ENR/carbon nanotube(CNT) were prepared in an open two-roll laboratory mixing mill at $50 \sim 60{ }^{\circ} \mathrm{C}$. Curing property and static mechanical property of NR/ENR composites with different fillers were investigated. Damping property of NR/ENR composites with different fillers was operated by dynamic mechanical analysis. Results showed that filler MMT and CNT when adding 10 parts per hundreds of rubber (phr) could enhance the damping property of NR/ENR composites, but lowered the mechanical property.

\section{Introduction}

With the development of society and the improvement of people's life, noise and vibration are causing more and more attention ${ }^{[1]}$. The key to solve the problem is to use damping rubber shock absorber, therefore, the use of high damping performance material becomes more and more popular.

Nowadays, rubber damping material is widely used in shock absorption area, mainly in automobile, locomotive, railway pad, bridge, architecture, and so on ${ }^{[2]}$. In the automotive applications, the annual demand for rubber shock absorber has reached several hundred millions, and the number is attempt to rise year by year. With the development of railway, the demand for rubber shock absorber is becoming larger and larger ${ }^{[3,4]}$. Moreover, the bridge bearing is also widely used rubber shock absorber ${ }^{[5]}$. And with the increasing frequency of earthquakes, rubber shock absorber used on building attracts people's attention and becomes processing damping area ${ }^{[6]}$. Now an important direction of damping material is to developing high damping performance in wide range temperature, so the research and development high damping material is very important.

Natural rubber is widely used material in high damping material for its comprehensive excellent mechanical properties and good damping properties. However, NR has low loss factor ( $\tan \delta)$ during working temperature. Epoxidized natural rubber, prepared by natural rubber, has controllable transition temperature, making it a potential material in damping industry. Therefore, ENR can be used as a blending rubber with NR could expand the damping temperature of NR.

Naturally, loss factor which can reflect the vibration energy is an important parameter to evaluate damping properties of material ${ }^{[7]}$. For rubber material, loss factor is closely related to damping property. If the transition temperature range is wide in a high loss factor range, that indicates excellent damping property.

High damping material is defined as high loss modulus, low storage modulus and wide temperature range during work condition. And there are different methods to improve material's damping property, including physical method and chemical method, for example, modifying the molecular structure, mixing different matrix adding different additive and using functional molecules. And filler also plays an important role in damping properties. 
In this study, damping composites with different filler were prepared. All compounds were prepared by mechanical mixing method and their damping property was investigated by dynamic mechanical analysis.

\section{Materials}

ENR40 (the extent of the epoxidation is $40 \%$ ) is prepared in our factory. Carbon black, Nanji Chemical Co. Ltd. $\mathrm{SiO}_{2}$, HL150, Jilin Shuangji Chemical Co. Ltd. MMT, Zhejiang Fenghong Clay Chemical Co. Ltd. CNT, Shenzhen Nano Port Co. Ltd.

NR/ENR composites with different filler were prepared in an open two-roll mixing mill at 50 $60{ }^{\circ} \mathrm{C}$. The rubbers were rolled in the mill for four times, filler, $\mathrm{ZnO}, \mathrm{SA}$, accelerators and sulfur were added in the rubber matrix. Optimum cure times were obtained from an Alpha Moving Die Rheometer at $150^{\circ} \mathrm{C}$. Then the vulcanizates were compression cured at $150^{\circ} \mathrm{C}$ for the optimum time. The resume is matrix, NR/ENR 80/20, NR/ENR/CB 80/20/10, NR/ENR/SiO 2 80/20/10, NR/ENR/MMT 80/20/10, NR/ENR/CNT 80/20/10. ZnO 4, SA 2, TBBS 0.7, S 2.25.

\section{Characterization}

Curing property was performed on an Alpha Moving Die Rheometer at $150^{\circ} \mathrm{C}$ for 30 minutes, and $\mathrm{T}_{90}$ was obtained.

Mechanical property was performed on an Instron 3365 machine with C-type dumbbell samples according to GB/T528-2009.

Dynamic Mechanical Analysis (DMA) of carbon black filled NR, NR/BR, NR/IIR and NR/ENR compounds are operated on a NETZSCH 242C Dynamic Mechanical Thermal Analyzer. The samples were performed in tension condition with temperature scanning from $-120^{\circ} \mathrm{C}$ to $100^{\circ} \mathrm{C}$ at a heating rate of $5^{\circ} \mathrm{C} / \mathrm{min}$, and the frequency used in the measurement is $3.3 \mathrm{HZ}$.

\section{Results and Discussion}

Curing property of NR/ENR composites with different fillers. Table 1 was the values of scorch time, optimum cure time, minimum torque and maximum torque of NR/ENR, NR/ENR/CB, NR/ENR/ $\mathrm{SiO}_{2}, \mathrm{NR} / \mathrm{ENR} / \mathrm{MMT}$ and NR/ENR/CNT compounds.

Table 1 Curing Parameters of NR/ENR compounds with different fillers

\begin{tabular}{ccccccc}
\hline Samples & $\mathrm{T}_{\mathrm{S} 1}[\mathrm{~min}]$ & $\mathrm{T}_{\mathrm{S} 2}[\mathrm{~min}]$ & $\mathrm{T}_{10}[\mathrm{~min}]$ & $\mathrm{T}_{90}[\mathrm{~min}]$ & $\mathrm{ML}[\mathrm{dN} . \mathrm{m}]$ & $\mathrm{MH}[\mathrm{dN} . \mathrm{m}]$ \\
\hline NR/ENR & 4.8 & 5.4 & 5.1 & 11.9 & 0.36 & 13.55 \\
NR/ENR/CB & 4.8 & 5.5 & 5.2 & 13.5 & 0.66 & 16.92 \\
NR/ENR/SiO 2 & 9.7 & 10.6 & 10.2 & 20.1 & 0.70 & 14.60 \\
NR/ENR/MMT & 7.2 & 8.1 & 7.3 & 17.9 & 0.33 & 10.96 \\
NR/ENR/CNT & 5.6 & 6.4 & 6.1 & 15.4 & 1.02 & 17.04 \\
\hline
\end{tabular}

In Table 1, it can be seen that the scorch time $\left(\mathrm{T}_{\mathrm{S} 1}\right)$ and the optimum time $\left(\mathrm{T}_{90}\right)$ of NR/ENR/ $\mathrm{SiO}_{2}$, NR/ENR/MMT and NR/ENR/CNT were increased compared to NR/ENR composites. That was because $\mathrm{SiO}_{2}$, MMT and CNT could absorb accelerator leading the curing efficiency lowered. Compared to $\mathrm{CB}, \mathrm{MMT}$ and $\mathrm{CNT}, \mathrm{SiO}_{2}$ added composties had the longest $\mathrm{T}_{\mathrm{S} 1}$ and $\mathrm{T}_{90}$, that was because there was pores in $\mathrm{SiO}_{2}$ surface, so could absorb more accelerator, leading to longest $\mathrm{T}_{\mathrm{S} 1}$ and T90.

Mechanical property of NR/ENR composites with different fillers. Table 2 was the mechanical properties of NR/ENR composites with different fillers. It is shown that stress properties and tensile strength of composites with $\mathrm{CB}$ and $\mathrm{SiO}_{2}$ was higher compared with NR/ENR composites. The stress at $100 \%, 300 \%$ and tensile strength of NR/ENR/CB composite were 1.27 MPa, 5.07 MPa and 29.48 $\mathrm{MPa}, \mathrm{NR} / \mathrm{ENR} / \mathrm{SiO}_{2}$ composite were 1.01 MPa, 3.24 MPa and 26.52 Mpa. However, tensile strength of NR/ENR/MMT and NR/ENR/CNT composites was lowered compared to NR/ENR composite, 
and tensile strength of NR/ENR/MMT was $13.3 \mathrm{MPa}$ and NR/ENR/CNT was $19.9 \mathrm{Mpa}$.That may be due to the shape of the filler. MMT was lamellar and CNR was tubulous, that made the filler attempt to aggragate in rubber matrix and lead to mechanical property decreasing.

Table 2 Mechanical properties of NR/ENR composites with different fillers

\begin{tabular}{lccccc}
\hline Samples & NR/ENR & NR/ENR/CB & NR/ENR/SiO 2 & NR/ENR/MMT & NR/ENR/CNT \\
\hline $\begin{array}{l}\text { Stress at } \\
100 \%[\mathrm{MPa}]\end{array}$ & 0.84 & 1.27 & 1.01 & 0.67 & 1.47 \\
$\begin{array}{l}\text { Stress at } \\
300 \%[\mathrm{MPa}]\end{array}$ & 2.31 & 5.07 & 3.24 & 1.75 & 5.44 \\
$\begin{array}{l}\text { Stress at } \\
500 \%[\mathrm{MPa}]\end{array}$ & 8.37 & 17.23 & 11.2 & 5.08 & 17.21 \\
$\begin{array}{l}\text { Tensile } \\
\begin{array}{l}\text { Strength } \\
{[\mathrm{MPa}]}\end{array}\end{array}$ & 25.31 & 29.48 & 26.52 & 13.30 & 19.90 \\
$\begin{array}{l}\text { Elongation at } \\
\text { break [\%] }\end{array}$ & 672 & 619 & 673 & 662 & 543 \\
\hline
\end{tabular}

Damping property of NR/ENR composites with different fillers. Fig. 1 was the dynamic property of NR/ENR composites with different fillers. Because loss factor ( $\tan \delta$ ) can reflected the damping performance of material, so $\tan \delta$ was used to evaluate the damping performance of the composites. It can be seen that tan $\delta$ curves of NR/ENR composites with different fillers were diverse. Compared to NR/ENR composite, $\tan \delta$ at the first peak of NR/ENR/ CB, NR/ENR/MMT and NR/ENR/CNT composite were lowered obviously, while $\mathrm{NR} / \mathrm{ENR} / \mathrm{SiO}_{2}$ lowered little. Compared to NR/ENR composite, $\tan \delta$ at the second peak of NR/ENR/CB and NR/ENR/ $\mathrm{SiO}_{2}$ had little change, while NR/ENR/MMT and NR/ENR/CNT became higher obviously. That was because lamelar and tubulous shape would block the molecular chain move and made the $\tan \delta$ higher.

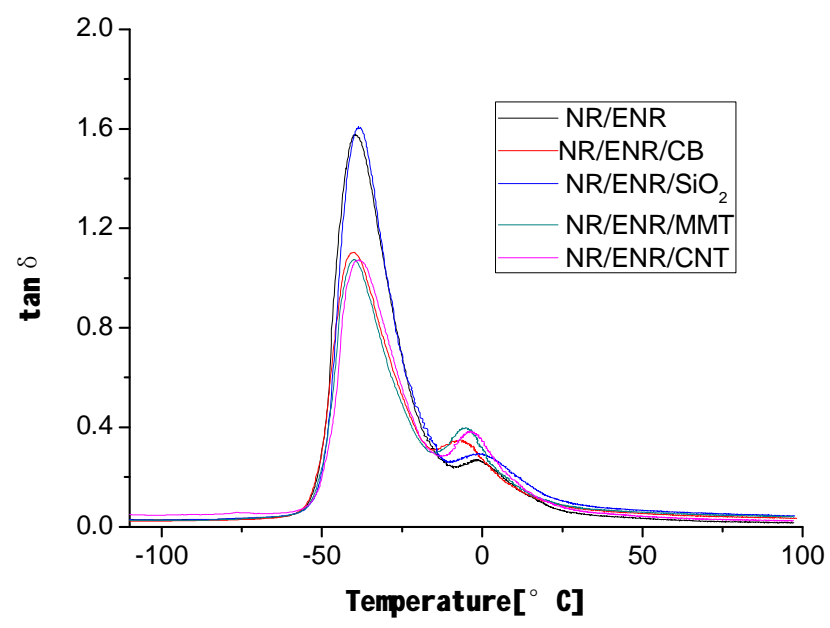

Fig. 1 loss factor curves of NR/ENR composites with different fillers

Table 3 illuminated the damping parameters of NR/ENR composites with different fillers. Generally, the working temperature of rubber material was between $-30^{\circ} \mathrm{C}$ and $60^{\circ} \mathrm{C}$, so integration area of $\tan \delta$ between $-30^{\circ} \mathrm{C}$ and $60^{\circ} \mathrm{C}$ was used to evluate the damping property. Moreover, $\tan \delta$ of material more than 0.3 was defined the valid damping effect, so the temperature range of tan $\delta$ more than 0.3 was also used to evaluate the damping property of composite.

Compared to NR/ENR composites, integration area of tan $\delta$ between $-30{ }^{\circ} \mathrm{C}$ and $60{ }^{\circ} \mathrm{C}$ of $\mathrm{NR} / \mathrm{ENR} / \mathrm{SiO}_{2}, \mathrm{NR} / \mathrm{ENR} / \mathrm{MMT}$ and NR/ENR/CNT composites were higher, that meant NR/ENR/ $\mathrm{SiO}_{2}, \mathrm{NR} / \mathrm{ENR} / \mathrm{MMT}$ and NR/ENR/CNT composites had better damping property. Compared the temperature range of $\tan \delta$ more than 0.3 , it can be seen that the temperature of $\mathrm{NR} / \mathrm{ENR} / \mathrm{CB}$, NR/ENR/MMT and NR/ENR/ CNT composites expanded to high temperature obviously, while 
$\mathrm{NR} / \mathrm{ENR} / \mathrm{SiO}_{2}$ nearly the same. Especially the NR/ENR/MMT composties expanded to $0.8^{\circ} \mathrm{C}$, the temperature range was increasing by $15.6{ }^{\circ} \mathrm{C}$ compared NR/ENR composite. In a word, NR/ENR/MMT had better damping property than other composites, but the mechanical properties should be enhanced.

Table 3 Damping parameters of NR/ENR composites with different fillers

\begin{tabular}{ccccc}
\hline Samples & $\begin{array}{c}\text { Tg at the first } \\
\text { peak }\left[{ }^{\circ} \mathrm{C}\right]\end{array}$ & $\begin{array}{c}\mathrm{Tg} \text { at the second } \\
\text { peak }\left[{ }^{\circ} \mathrm{C}\right]\end{array}$ & $\begin{array}{c}\text { Integration area of tan } \delta \\
\left.\text { between[-30 }{ }^{\circ} \mathrm{C}, 60^{\circ} \mathrm{C}\right]\end{array}$ & $\begin{array}{c}\text { Temperature range } \\
\text { of tan } \delta>0.3\left[{ }^{\circ} \mathrm{C}\right]\end{array}$ \\
\hline NR/ENR & -39.9 & -2.4 & 17.86 & {$[-50.0,-14.8]$} \\
NR/ENR/CB & -41.1 & -7.6 & 17.84 & {$[-50.0,-1.3]$} \\
NR/ENR/SiO 2 & -38.9 & -1.7 & 20.73 & {$[-48.8,-14.1]$} \\
NR/ENR/MMT & -39.9 & -6.2 & 18.3 & {$[-49.0,0.8]$} \\
NR/ENR/ CNT & -39.4 & -3.9 & 18.67 & {$[-48.2,-15.0]$,} \\
& & & & {$[-9.6,1.5]$} \\
\hline
\end{tabular}

\section{Conclusions}

Mechanical property and damping property showed that damping performance can be effected by filler with different shape. Filler with lamelar and tubulous shape could enhance the damping property of composites, but due to the aggregation in rubber matrix, mechanical property of composites decreased. In a word, if the dispersion of lamelar and tubulous filler could been solved, using lamellar and tubulous filler may prepare high performance damping composites.

\section{Acknowledgements}

This work was financially supported by Special Fund for Agro-scientific Research in the Public Interest (201403066), the Earmarked Fund for China Agriculture Research System (CARS-34-JG2), the Major Science and Technology Plan Project of Hainan Province (ZDKJ2016020), Guangzhou Science and Technology Board project(201604010059) and Funded by Central Public-interest Scientific Institution Basal Research Fund for Chinese Academy of Tropical Agricultural Sciences (1630122017005).

\section{References}

[1] Y. Cao, D. Stanescu: Computers \& Mathematics with Applications Vol. 44 (2002), p. 1527

[2] C. Deng, D. Mu, X. Jia, Z. Li: Photonic Sensors Vol. 6 (2016), p. 372

[3] L. Yu, S. Liu, L. Ye, G. Huang, Y. Xu: Journal of Wuhan University of Technology-Mater. Sci. Ed. Vol. 27 (2012), p. 130

[4] C. Hidalgo Signes, P. Martínez Fernández, E. Medel Perallón, R. Insa Franco: Materials and Structures Vol. 50 (2016), p. 102

[5] A. Hameed, M.-S. Koo, T. D. Do, J.-H. Jeong: KSCE Journal of Civil Engineering Vol. 12 (2008), p. 187

[6] S. Bandyopadhyay, A. Sengupta, G. R. Reddy: Earthquake Engineering and Engineering Vibration Vol. 14 (2015), p. 683

[7] V. G. Geethamma, R. Asaletha, N. Kalarikkal, S. Thomas: Resonance Vol. 19 (2014), 821 